NHER HORKING PAYER SERIES

ON TIIE DIVERGENGE IN UNIONISM AMONG DEVELOPED COUNTRIES

\title{
Richard Freeman
}

Working Paper No. 2817

NATIONAL BUREAU OF ECONOMIC RESEARCH

1050 Massachusetts Avenue

Cambridge, MA 02138

January 1989

This research is part of NBER's research program in Labor Studies. Any opinions expressed are those of the author not those of the National Bureau of Economic Research. 
NBER Working Paper $\approx 2817$

January 1989

ON THE DIVERGENCE IN UNIONISH AMONG DEVELOPED COUNTRIES

ABSTRACT

In this paper I explore the evolution of unionism in the 1970 s and 1980s, when the post-oil shock world economy created a "crisis of unionism" throughout the western world. I try to explain why union representation of work forces fell in some countries but not in others and contragt union responses to the challenge of the period. I find that:

- Rates of unionisation diverged greatly among developed countries

- The composition of union members shifted from private sector blue collar workers to public sector end white collar workers in all countries, producing increased divisions within union movements by category of worker

- Changes in the industrial composition of employment, changes in public attitudes toward unionism, and the growth of governmental protection of labor do not explain the divergence in density

- Differing rates of inflation contributed to the divergence, with unions doing better in countries with high inflation. In addition, unemployment raised density in settings where unions disperse unemployment benefits

- The primary reason for the divergence are differences in the incentives and opporcunities different industrial relations systems give employers to oppose unions. Unions fared best in neo-corporacist settings and worst in settings where decentralised bargaining creates a strong profit incentive for managers to oppose unions and where management is relatively free to act on that incentive

- Union organizations and modes of operating changed significantly in some countries with declining or endangered unionism but not in others

Most strikingly, my analysis indicates that if 1980 s trends continue the west will be divided between countries with strong trade union movements operating. in a neo-corporatist system, as in Scandinavia, and countries with 'ghetto unionism' limited to special segments of the work force, as in the United States. 


\section{On the Divergence of Unionlsm anong Developed Countries}

\section{INTRODUCTION}

In this paper I explore the evolution of unionism in 1970 s and 1980 s when the post-oll shock world economy created a "crlsis of unionism" throughout the western world. I try to explain why union representation of work forces fell in some countries but not in others and contrast union responses to the challenge of the perlod. I find that:

1) Rates of unionisation diverged greatly among developed countries (Section 2.1)

2) The composition of union members shifted from private sector blue collar workers to public sector and white collar workers in all countries, producing Increased divisions within union movements by category of worker. (Section 2.2)

3) Changes in the Industrial composicton of employment, changes in public attitudes toward unionism, and the growth of governmental protection of labor do not explain the divergence in density (Section 3.1)

4) Differing rates of Inflation contributed to the divergence, with unions doing better in countrles with high Inflation. In addition, unemployment ralsed density in settings whore unlons disperse unemployment benefits. (Section 3.2; Section 3.5)

5) The primary reason for the divergence are differences in the incentives and opportunities different industrlal relations systems give employers to oppose unions. Unions fared best In neo-corporatist settings and worst In settings where decentralised bargalning creates a strong profit incentive for managers to oppose unlons and where management is relatively free to act on that incentive. (Section 3.3; Section 3.5)

6) Union organizations and modes of operating changed significantly in some countries with declining or endangered unionism but not in others. (Section 3.4) 
Most strikingly, my analysis indicates that if 1980 s trends continue the west will be divided between countries with strong trade unfon movements operating in a neo-corporatist system, as In Scandinavia, and countries with 'ghetto unionism' limited to spectal segments of the work force, as in the U.S.

\section{CHANGES IN UNIONISM AMONG DEVELOPED COUNTRIES}

In contrast to business firms, which behave similarly in all capltalist countries, maximizing profits or something close akin, trade unlons have a "national" dimension, operating under distinct institutional arrangements across countries. In the United states unions negotlate detalled collective bargaining contracts with firms; In Sweden they are Involved in national wagesetting and neo-corporatist social agreements; In Australia they argue wage cases before arbitration tribunals; in France they negotiate industry or regional minima that are extended to entire sectors; In Japan they represent workers at the company leve 1 and organize the shunto offensive; etc. Separated by national barrlers, unlon movements are like distinct species of animals, developing differently in some dimensions even in similar economic and technological environments. In the 1970 s and 1980 s the union representation of workers underwent particularly dramatic changes across developed countries, rising in some countrles to reach virtually complete organisation of the work force, whlle falling sharply in other countries. At the same time the composition of untonised labour underwent simllar changes across countries, as the white collar and public sector worker share of union members rose while the manual and private sector manufacturing workers share of members fell.

\subsection{Divergence in Union Density}

The first and seemingly simplest fact to establish is the claimed divergence in union density among countries. Because counts of union membership include large numbers of the unemployed or of pensioners in some 
countries but not in others; come from diverse sources - - labor force surveys, reports by unions, employer surveys, unfon financlal records (see Eurostat for a detalled comparison of unlon data by country); and reflect differences in what unions do In different settings, however, the seemingly simple is fraught with problems. As examples of the difficulties in cross-country comparisons note the following: In Australia unlons represent virtually all workers before the tribunals that formally set wages but enligt only half of the work force: In France and Germany unions have a larger role in wage-setting than density figures Indicate because agreements between representative employers and unions are legally extended to other employers; In Italy the growth of autonomous union groups in the public sector and of quadri among foremen and lower level management makes membership data from the major confederations an incomplete Indicator of unton organisation (MInestero del Lavoro e della Previdenza Sociale, 1988). These and other data/conceptual problems mean that even the most careful estimates of density provide only crude Indicators of crosscountry differences in union strength and must be Informed by direct knowledge of Institutions so as not to be misleading.

This said, exhiblt 1 records estimates of the unlon proportion of nonagricultural wage and salary workers in OECD countrles from 1970 to the mid1980s. While comparisons of changes in density over time are less likely to be distorted by cross-country differences than are comparisons of levels, even the trends are not problem free. The UnIted KIngdom figures understate the 1980s decline in British density as some unions exaggerated membership to maintain high representation In the Trade Union Congress and Labor Party. The American data mix two opposing trends: a disastrous drop In private sector density and a spurt in public sector unionism. The Itallan data may overstate the 1980s drop due to absence of membership outside the three confederations. 
Measurement issues notwithstanding, exhibit 1 shows a divergence in densicies that is unlikely to change wlth better data. From 1970 to 1979 density increased in most countries, rising 10 or so points in several, but fell in the United States, Japan, and Austria. From 1979 to $1985 / 86$ density dropped in the United KIngdon, the Netherlands, and Italy as well as in the U.S. and Japan while stabilizing in most other countries. Two decades of decline make the U.S. and Japan the centers of de-unionisation, greatly reducing their share of union membership in the West. In 1970428 of all unlon members of the countries in the exhibit were American or Japanese. In 1985/86, despite an Increase in the American and Japanese share of wage and salary workers from 50 to 548 the two countries accounted for only 34 of union members. (1) As a result of the different trends In unionisation, the coefficlent of variation of density rose from .31 in 1970 to .39 in 1985/86.

Note, finally, that density changed differently between pairs of countries with simflar Industrial relations systems -- the United States and Canada; the United KIngdom and Ireland, Netherlands and Belglum - Indicating that the diverging trends represent more than disparate development of greatly different forms of unionism. The differing evolution of unions between close palrs suggests that relatively modest differences in industrial relations laws and Insticutions can signiflcanty affect the evolution of unionism.

\section{2 membersh1p composition}

Desplte differing trends, the composition of union membership in virtually all countries shifted in the 1970 s and 1980 s from the blue collar private sector workers who constituted the vast majority of members in earlier decades to public sector workers and in some countries to white collar private sector workers as well (see exhibit 2). In the United states, where the public sector was viewed as unorganizable in the 1950s and 1960s, state and local legislation legallzing public sector collective bargaining spurred huge increases in union 
ExhIBIT 1: Levels and Changes in Union Membershdp as a Percent of NonAgricultural Wage and Salary Employees Across Countries. 1970-1986.

Countries with aharp

Risea in Density

Denmark

Finland

Sweden

Belgiuma

Countries $v / 1970^{\prime} \mathrm{a}$

Rises In Dansity/

Btable In $1980 \%$

$\begin{array}{llll}66 & 86 & 95 & +20 \\ 56 & 84 & 85 & +28 \\ 79 & 89 & 96 & +10 \\ 66 & 77 & -- & +11\end{array}$

$1979-86 \quad 1970-86$

$\begin{array}{ll}+9 & 29 \\ +1 & 29 \\ +7 & 17 \\ -- & --\end{array}$

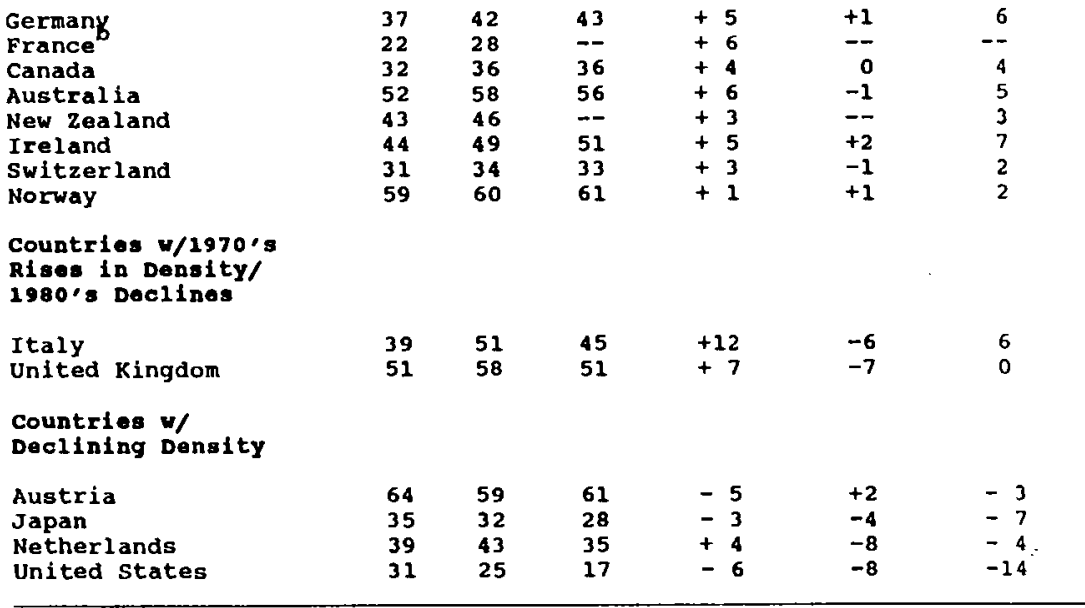

BOURCE: U.S. Bureau of Labor statistics

London School of Economics OECD Data Set, updated using relevant Country statistical Abstracts

a Visser excludes pensioners, and reports: 558 in 1970,698 in 1979, and 748 in 1983.

b Visser reports densities of 26,24 , and 21 , which would put France in declining density. 
Exhibit 2: Public Sector and Private Sector Blue Collar Shareg

of Union Membership, by Country

\begin{tabular}{|c|c|c|c|c|c|c|}
\hline \multirow[t]{3}{*}{ Country } & \multicolumn{2}{|c|}{ Private Sector } & \multirow[t]{3}{*}{ Change } & \multicolumn{3}{|c|}{ Public Sector Share } \\
\hline & Blue Gollar & Share & & of Unton & lembers & \\
\hline & 1970 & $1980 \mathrm{~s}$ & & 1970 & $1980 \mathrm{~s}$ & \\
\hline United States & 67 & 54 & -13 & 14 & 36 & 22 \\
\hline United Kingdom & 55 & 45 & -10 & 34 & 39 & 5 \\
\hline Japan & -- & -- & -- & 29 & 29 & -- \\
\hline Ganada & - & $\cdots$ & $\cdots$ & 26 & 45 & 19 \\
\hline Ge rmany & 54 & 48 & -6 & 33 & 35 & 2 \\
\hline Italy & 65 & 55 & -10 & 18 & 24 & 6 \\
\hline Sweden & 45 & 32 & -13 & 36 & 44 & 8 \\
\hline Austria & 52 & 44 & -8 & 33 & 35 & 2 \\
\hline Netherlands & 51 & 39 & -12 & 37 & 46 & 9 \\
\hline SwItzerYand & 50 & 46 & -4 & 29 & 30 & 1 \\
\hline
\end{tabular}

Source: U.S., 1980s from U.S. Bureau of Labor Statistics, 1988

1970, from U.S. Bureau of Labor Statistics, 1972, where I

estimate the private sector blue collar union memebers by subtracting public

sector members outside public administration and services from blue collar.

Japan, from Japan Ministry of Labor, March 1, 1971 and April 1, 1985

Cansda, 1970 is 1971 from Wood and Kumar (1977); 1980s from Kumar

(1986). I have taken union workers in public administration plus 898 of those

in the services (-education and health and welfare share of union members in

services in 1986) as estimate of unton membersh1p in government jobs.

A11 others, from Visser 1985 
membershlp and collective bargaining representation (Freeman and Ichniowski, 1988) with dramatic effects on the public sector share of unionists due to the decline in private sector membership. In countries 1 ike Denmark and Sweden, where blue collar private sector organisation races were high at the outset of the perlod, growth was necessarily concentrated among public sector and white collar workers. In Canada, public sector membership expanded rapidly, partly as a result of favorable public sector labor laws, while private sector density drifted downward. One reason for the increased attractiveness of untons to public sector and white collar workers was a perception that they needed unions to maintain real wages during the 1970 s rapid Inflation. Once established, moreover, public sector membership tends to be more stable than private sector membership due to the stab111ty of public employment.

The shift to white collar and public sector membership has begun to change the face of union movements traditionally dominated by industrial workers. In the U.S. the locus of power in the AFL-CIO la shifeing to public sector organizations while the non-affiliated National Education Association has achleved considerable national influence. In Italy the new autonomous public sector organizations and quadri pose a challenge to the three traditional confederations. In Sweden and Denmark the white collar unions have shown an Increasing willingness to develop their own economic agenda rather than to follow the lead of blue collar manufacturing unions.

\section{REASONS FOR THE DIVERGENCE}

Several hypotheses can be advanced for explaining the divergence in density: changes in the composition of employment, in atcitudes toward unionism, and in governmencal protection of labor which reduce worker desires to organise; macro-economic developments; management opposition to unionism; and differential responses of union movements to the problems of the period. 


\subsection{Structural Explanations}

One often suggested explanation for changing unionisation are differential changes in the composition of employment among fobs or workers, which in the 1970 s and 1980 s took the form of a shift toward traditionally less untonized areas, In countries where employwent shifted rapidly from manual to white collar Jobs, from goods to service Industrles, from small to large firms, and from female to male or from less educated to more educated workers, unions are, after all, likely to have greater difflculties organlzing than in countries where those shifts occur more slowly.

The shift hypothesis does not, however, stand up to scrutiny. Shifts in the composition of employment cannot explain divergent country experiences because shifts have occurred similarly across countries: the share of employment in manufacturing fell, for example, by roughly as wuch in high and Increasing density Sweden, Ganada, or Denmark as In the de-untonising U.S. or Japan. (2) Contrary to the shift hypothesis, moreover, large changes in union representation are accompanied by changes In density within sectors, as exhibit 3 demonstrates for countries with declining unionism.

A second possible explanation for diverging unton density is that public opinion of unions has come to differ greatly among countries. Perhaps density Is declining in countries where the public has less favorable atcleudes and Increasing/stabllizing in those where the public has more favorable attitudes. Lipset (1986), for one, has argued that reduced public approval is a major cause of the decline In American union density.

I reject this hypothesis as Inconsistent with within-country and crosscountry and evidence. Flrst, there is Iftte relation within countries between changes In opinton polis and In union density. Polls for the U.K. show that attitudes toward unfontsm became more favorable during the 1980 s decline in unionism; whlle those for the U.S. show public approval of unions steady 
between 1972 and 1985 when density fell sharply in the private sector and rose In the public sector, where public oplnion ought to be especially 1mportant. (3) Horeover, for what it is worth, cross-country opInion poll data show no substantial differences in approval of unions between countries with decreasing density and those with stable density: "polls show about a 33 percent (confidence) In the United States... higher than In Britain (26 percent) and Italy (32 percent) and scarcely worae than German and France (both 36 percent)" [Hecksher, 1988, 258]. Perhaps most strikIngly, comparisons of op Inion polls between the United States and Canada show that Canadians have, If anything, less favorable attitudes toward unions than Americans (Chalson and Rose, 1988), which runs counter to the decline in density In the United States and stable density In Canada.

A third posalbility 18 that the divergence results from differential changes in worker need for unlonlsm among countries. Perhaps governiental protection of labor Increased more In some countries than others, offering a substitute for unlonism (Neuman and R1ssman (1984) argue that this explains the decline of unions In the United States). Perhaps wages and personnel practices improved wore in some councrles than In others, offering a substitute for unlonlsm.

There is compelling evidence agalnst this hypothesis. First, unionism has remalned strong in Scandinavia and other European countries with highly regulated markets while losing strength in the United States under Reagan and In the Unlted Kingdom under Thatcher - - the opposite of what one would expect If governmental regulations substitute for union protection at work places. Within-country evidence is also inconsistent with the government substitution hypothesis: In the United States unions have done no worse in states with the greatest legal protection of labor than in those with the least (Freeman, 1987; Block, Mahoney, and Corbitt, 1987). At a conceptual level the argument that 
Changes in Union Density by sector: o.8., canede and Jepan

\begin{tabular}{|c|c|c|c|c|c|c|c|c|c|}
\hline \multirow[b]{3}{*}{ Tota 1} & \multicolumn{3}{|c|}{ United states } & \multicolumn{3}{|c|}{ Canada } & \multicolumn{3}{|c|}{ Japan } \\
\hline & $1973 / 5$ & 198 & $\Delta$ & 1975 & 1984 & $\Delta$ & 1975 & 1986 & $\Delta$ \\
\hline & 29 & 18 & -11 & 35 & 37 & 2 & 34 & 28 & -6 \\
\hline Manufacturing & 37 & 24 & -13 & 49 & 45 & -4 & 40 & 33 & -7 \\
\hline Construction & 38 & 22 & -16 & 63 & 39 & -24 & 18 & 19 & $\mathbf{1}$ \\
\hline $\begin{array}{l}\text { Transportation } \\
\text { Communication } \\
\text { utilities }\end{array}$ & , & 35 & -15 & 56 & 60 & 4 & 66 & 56 & -10 \\
\hline Service & 7 & 6 & -1 & 15 & 38 & 23 & 26 & 19 & -7 \\
\hline Mining & 35 & 18 & -17 & 47 & 33 & -14 & 41 & 42 & -1 \\
\hline Trade & 11 & 7 & -4 & 9 & 13 & 4 & & & \\
\hline $\begin{array}{l}\text { Finance, } \\
\text { Insurance } \\
\text { Real Estate }\end{array}$ & 4 & 3 & 1 & 1 & 9 & $\mathbf{8}$ & 20 & 18 & -2 \\
\hline Government & 24 & 36 & 12 & 73 & 67 & -6 & 67 & 69 & 2 \\
\hline
\end{tabular}

SOURCE: U.S. 1973/5: Richard B. Freeman and James Medoff (1979) with government estimated from May 1973-75 current population Survey Tapes.

U.S. 1986: U.S. Bureau of Labor Statistics, Jan.1988.

Canada: Pradeep Kumar, "The current Industrial Relations Scene in Canada: 1986" (Queens Univ, Kingston, Canada)

Japan

1970 1986: Japan Ministry of Labor, Bas 1c. Survey of

Trade Unions. Forelgn Labor Trends. 
unionism and goveriment regulation are substitutes is flawed because it fails to recognize that "enacting a law and securing the realization of the purpose the law Is almed to sacure are two vastly different matters" (Gompers, 1965, p. 54). To beneflt fron legal regulation workers need a union or union-11ke agency to monitor compliance at tho shop floor. As for the substitution of good exployeent practices for unlonisu, while high wages and posftive Industrial relations can deter unionisation, the large firms that pay abovemarket wages and have progressive human resources policies - - of which IBH Is the examplar - .employ similar moderate and declining proportiong of work forces In Industrial economies (OECD, 1986). Changes In unlon density are, moreover, uncorrelaced with levels or changes in real wages across countrles, contrary to what one would expect if high or Improving pay reduced the desire for unions (4).

If none of the above explains the divergence in densfty, what does?

\section{2 MACRO-ECONOMIC FACTORS}

One $11 \mathrm{kely}$ factor is the differing macro-economic experiences of countries. On the basis of studies of the cyclical pattern of union growth, high unemployment, low Inflation, and slow economlc growth ought to reduce unionism whl le the opposite conditions should Increase density. (5)

To explore this hypothesis I contrast in exhibit 4 the growth of employment and GDP per capita, the rate of Inflation, and the rate of unemployment between countries with increasing, decreasing, and roughly stable union density. The resules are, with the exception of Inflation, racher mixed. Rapld Inflation is assoctated with unton growth, presumably because nonunion workers see a need for contractual arrangements to preserve real earnings. Employment growth is higher in declining union density countries while growth of GDP per caplta and most strikingly, unemployment rates do not differ noticeably. As will be shown 


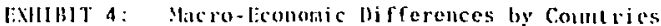
with llifferent Changes in Inion Density, $1980-1985 / 6$

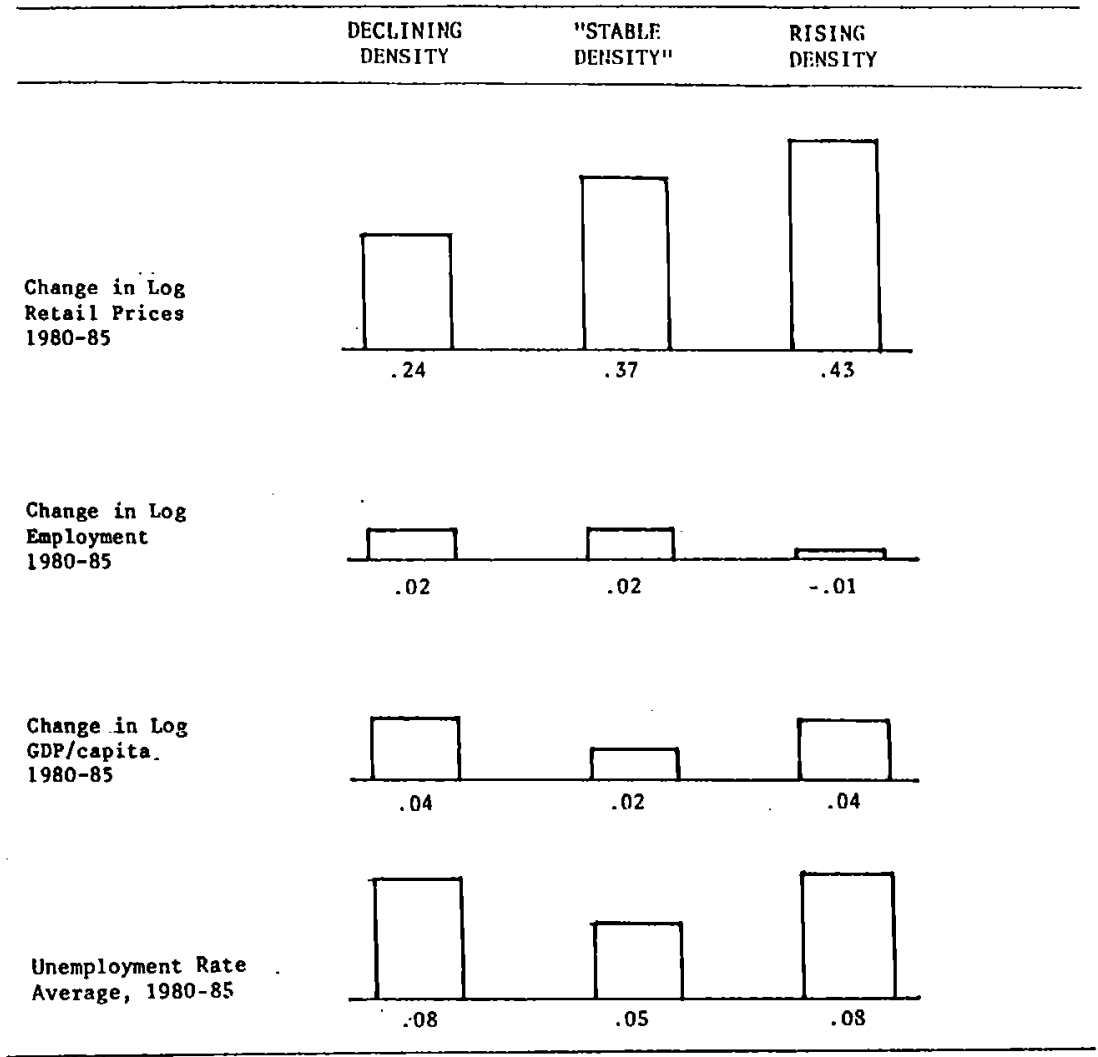

NOTES: Figures are averages for countries.

Declining Density Countries defined as United States, Japan, United Kingdom, Netherlands.

Increasing Density Countries defined as Denmark, Sweden, Belgium, I reland.

other Countries: all others from Exhibit 1. 
iu Exhibit 6 these patterns or lack of patterns hold up in multivariate regressions covering longer periods of time. The lack of a linear relation between unemployment and changes in density is partly attributable to the concordance of high unemployment and Increased union density in BelgIum and Denark - two countries where for historical reasons unions disperse government-funded unemployment benefits (as In Sweden and Finland), Inducing workers who lose jobs to maintain or join unions in poriods of increasing unemployment.

\section{3 MANAGEMENT OPPOSITION TO UNIONISM}

The factor that, I believe, explains best the divergence In union experiences are differential changes in the difficulty of organising new workers due to changes in the lovel and effectiveness of management opposition to unionism. Here, the rapidly de-unionising United States is the prima facie case of what aggressive management can do to unionism. In the 1970s and 1980 s U.S. management turned against unions and collective bargaining to a degree not seen anywere else In the free world. VIrtually all firms that faced National Labor Ralations Board representation electlons (the government-run secret ballot procass by which American workers can choose to uniontse) angaged in expensive aggressive campaigns to persuade/pressure workers to reject unions. Unfalr labor practices of diverse forms (Including firing upwards of a thousand union activists in a year) skyrocketed to ratea five or six times those in earlier decades. Large nonunion firms consclously copled union sentority and grlevance procedures to deter employee Interest in unions. Forty-five percent of the relatively progressive firms In the Conference Board's Personnel Forun declared in 1983 that operating 'union-free' was their main labor goal (Kochan, McKersie, and Chalykoff, 1986) - a far cry from the 1950 s and 1960s when most large firms accepted unions at the work place. Even when workers voted to 
unlonise, moreover, management avolded a first contract in one-third of the cases, effectively negating the election. On the basis of diverse studies that show management opposition to have been a major factor in the fallure of unions to organlse In the perlod (Freeman, 1985), most analysts have come to belleve that it is a, if not the, major cause of the decline in private sector density. Why did American management declare war on unions? One reason is that unionism became more costly to firms. It became more costly because the union wage premium rose In the 1970s (Freeman, 1986) and because growth of trade, deregulation, and other factors Increased product market competition, making It more difficult to pay above-market wages. A second reason is the growth of a mllitant market-orlented Ideology that fugtified virtually any anti-union action as preserving managerial flexibllity. A thled reason is the devolopment of a sophlsticated union-prevention technology that exploits the opportunteles U.S. labor laws givo management to campalgn against unions. In Canada, where labor Law limits management's abllity to flght unlons, often by certifylng unions after card checks, many of the same firms that go all out to defeat unlons in the U.S. accept unlonisation of thelr Canadian plants.

Is management opposition important in other countries with rapidly declining density?

In the United KIngdom, the princlpal cause of the 1980 s drop In density appears to be the Thatcher government's Industrial relations laws, which shifted the balance of power at vorkplaces to management and weakened the ablilty of unions to organise. (Freeman and Pelletler, 1989) Wh1le management opposition to unionisw has not taken the form or virulence shown in the U.S. the new features of the law have enhanced resistance to union activities.

In Japan, government and management opposition have played a major role in the drastic loss of membership of Kokuro, the mllitant union of now privatized 
Japunese National Rallway. Once the largest rallway union whth over 500,000 members, in 1988 it had only 42,000 members due to management's union busting tact1cs. (Nagash1ma, 1988) S1milarly, the Japanese Teachers Union has suffered major losses of membership due In part to government efforts to discourage newly-hired teachers from joining the unlon. More Importantly, data on the number of workers newly organised shows a pattern remarkably like that In the United states, with the bulk of the drop in unionism attributable to a precipltous fall in union organisation of new workers relative to the growing work force. The drop in new organisation occurred after the ofl shock placed severe economic pressures on Japanese employers, was accompanled by changes In court Interpretation of labour law favorable to managment, and was concentrated In Industries faclng the greatest profits squeeze (Freeman and RebbIck, 19B9) Given the close tles between companies and unions in an enterprise union system, and the role of white collar employees in company unions. I find it hard to belleve that changes in company attitudes toward unionism has not played a role in the Inablitty of untons to organise new workplaces.

In Italy and the Netherlands, management opposition of the American or rilder British type would appear to have little to do with the observed changes. The 1980 s decline in density In Italy has been attributed to the disorganisation of the unlon movement that developed after 1983. The 1980s decline In density in the Netherlands may be largely the result of the high unemployment that developed In the mid-1970s and persisted for over a decade.

What about management behavior in countrles where union density reached unprecedented peaks in the perlod under study? If differences in management opposition contributed to the divergence, one would expect less opposition in those countries, elther because firms have little profit incentive to avold unionism or little legal or Institutional opportunity to express opposition. 
The prise factor that appears to reduce the profit incentive to fight unions is centralized wage negotiations. In countries where unions and management engage in national bargaining -- so-called neo-corporatist systems -managements form employers' federations to establish going national wages and often pressure nonunion firms to recognize unlons, presumably to assure that they pay the going rate. The notion that business should engage in a jhad for union-free environment as in the United States is anathema to employers in such a setting. Unionism has accordingly fared well, with density increasing in the 1970 s and 1980 s even though density was already high at the outset of both periods (exhibit 5).

Countrles where the state extends collective contracts to nonunion firms such as Germany and France and where workers are represented by works counc1ls (much of Western Europe) might also appear to give employers little reason to oppose unions at the plant level. Here, however, the likelihood that plantlevel agreements will go beyond representative contracts suggests that employers w1ll be more opposed to unions than in neo-corporatist settings. In fact, unionisation trends in Germany and in France (as best one can tell from avallable data) are intermediate between those of the U.S., U.K. In the Thatcher era, and $J$ apan and the neo-corporatist countries.

Finally, the growth/stabllity of unionism in Canada and in Ireland shows that even in Industrial relations systems where management has a substantial profit Incentive to oppose unions legal restrictions on opposition can produce developments that differ from those in nelghboring countries (U.S. and U.K.) where the laws are less favorable to organisation. 
ExHlbl1 5: Percentage Point Changes in Union Density. $1970.85 / 86$

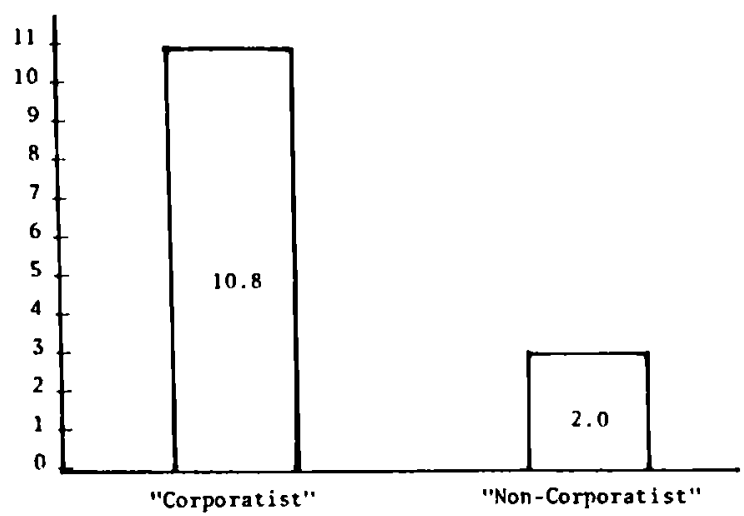

Source: Corporatist countries taken from Crouch.

They include: Austria, Denmark, Finland, Netherlands, Norway, Sweden, Shitzerland, and west Germany. 


\subsection{UNION RESPONSE}

Another likely cause for diverging unton densities are cross-country differences in unton responses to economle changes. Sidestepping wage setting (most union movements moderated wage demands relative to Inflation for the sake of Job security or to reduce unemployment) and atrike behavior (strike days lost fell in the $1980 \mathrm{~s}$ in all countries) there was a wide range of union organizational responses to the crisis of the 1970 s/80s.

The Australian union movement made perhaps the most dramatic adjustment to the new economic environment. After careful study of the German and Swedish experlences, the Australian Councll of Trade Unlons (ACTU) sought to transform Australian Industrial relations from a confrontational British-style system to a neo-corporatist system, In part to preempt growing anti-union management sentiment that might fuel U.S. or U.K. type losses of membership. In the mid 1980s the Secretary-Treasurer of the ACTU was dolng his best to convince constituent unlons to accopt a national wages accord that required some unions to take lower wage settlements than they could otherwise get.

The American labor movement reacted more slugglshly. In the 1970s many top AFL-Cro leaders downplayed falling density on the grounds that absolute membershlp was stabla and that an economic boom would cure all. In 1978 the Federation trled but falled to get a modest labor law reform bill. It was not unt11 1985 that top leadership sounded alarm bells with "The Changing Sltuation of Workers and the Ir Unlons" report. Since then national unlons have been slow to adopt the "evolutionary blueprint" lald out In the report. While many now offer unfon Mastercards with atractivaly low rates of Interest for their nembers (McDonald, 1987) few have actively pursued the key recommendation to create new forms of membership outside the collectlve bargaining structure. A major reason for the slow adaption is the decentralized structure of 
organfzed labor, which consists of soge 90 or so independent national unions in the AFL-CIO; others outside the federation: and hundreds of Independent locals within the national unions. Each national and local has 1 ts own concerns, guaranteeing slow response to problems that affect unionism in general and making problematlc implementation of reforms recomended by the AFL-CIO.

In the United KIngdow there has been a similar effort to devise new benefits (of the U.S. mastercard type) to attract workers. There have also, however, been more dramatic changes in Industrial relations practices In some sectors: the Miners Union split; the Electriclans and Englneering unlons have developed cooperative single plant/single union bargaining strategles; the Bollermakers, among others, have sought to enlist part-time workers. The b1g organizational change 18, however, be the splitting of the Trade Union Congress when it revoked membership of the Electriclans in September 1988.

In some other countries where unions have been in trouble, there have been structural changes In union organizations. In Japan, two federations, Dome1 and Churltsu Roren, have dissolved and thelr private sector unions have formed the new federation Rengo to break free from the more politicized public sector unlons. Sohyo plans to dissolve Itself in 1990. In Italy, the three majpr confederations, which united briefly in the early 1980s, separated to engage in competitive recrulting efforts, each with its own style and seling points.

\section{5 regression analysis}

To estimate the quantitative lapact of some of the aformentioned factors on cross-country changes in union density, I pooled data on density and Its determinants across 18 developed OECD countries for the period 1973-1985 and estimated a regression model linking changes (d) In density (DENS) to: a dummy varlable for corporatist Industrial relations (CORP); the rate of Inflation (INF); changes in the unemployment rate (UNE); a dummy variable for union delivery of unemployment benefits Interacted with changes in the unemployment 
rate (UI*dUNE); and selected other variables (Z). Because density is bounded between 0 and 1 I use a $\log$ odds ratio form as well as a 11 near form:

dDENS or dln(DENS $/ 1$-DENS) - a + bINF + cdUNE + UI*dUNE + eCORP + fz + u, where $\mathrm{Z}$ - set of variables that includes growth of employment and growth of GDP per capita and a vector of dumy variables for Individual years. Controling for Individual years removes common cyclical variation from the data to focus on the cross-country differences of concern.

The regression estimates sumarized In exhlbit 6 show that, consistent with the simpler tabulations given earlier, density grew more in countries with corporatist Industrial relations; with rising unemployment when unions deliver unemployment benefits; and with rapid inflation.

\section{CONCLUDING COMENTS}

Th1s atudy has shown that, contrary to the view that Industrial relations converges as countries develop (Kerr, Dunlop, Harbison, and Meyers), union density diverged among developed countries in the 1970s and 1980s. As all of the countries are advanced capltalist economies undergolng similar economic changes, the divergence implies that relatively modest differences in the Institutions that govern labor relations extert a substantial influence on the evolution of unionism. The decline In union density in the United States and Japan, where unions were thought to be part of the established order, furthur Implies that private sector unionism is a more fragile Institution than is widely recognized. The broad implication is that in a world of economic and social flux the structuring of labor relations is not a once-and-for-all process of setting up procedures and institutions. Rather, it is a process that must be undertaken time and again as environmental changes alter the balance of power between workers and management and thelr conflicting and coincident interests. There is no rest in the practice or study of Industrial relations. 
EXKIBIT 6: Impact of corporatism, Inflation, and changing Employment on Annual Growth of Percent Unionized 1970-1985

Explanatory Varlables

Dependent variables

Change in

Change in Log Odds

* Union

Ratio of Union

(Mean in parenthesis) (t statistice in parenthesis)

Corporatism (.48)

$.005(2.53) \quad .036(3.61)$

Inflation (.079)

$.065(2.60) \quad .406(2.99)$

Change in Unemployment (.003)

$-.109(0.77) \quad-.655(0.83)$

Change in Unemployment if

Unions Give Benefits (.0009)

$.823(4.19) \quad 6.31 \quad(5.81)$

Growth of GNP $(.028)$

$-.054(1.18) \quad-.19(.74)$

Time

$-.001(5.30) \quad-.004(3.26)$

R-Squared

Number of Observations

259

259

SOURCE: Calculated from London School of Economics,

Center for Labour Economics OECD Data set

Countries where unions give benefits:

Denmark, Belgium, Sweden and Finland

Corporate Countries, as in Exhibit 5 . 


\section{Endnotes}

1 -- I calculated the coefflelent of variation for $1985 / 86$ using 1979 densitles for Belgium, France, and New Zealand. The average density for the top six countries was 658 in 1970 and 798 In 1985/86 while the average density for the bottom six countrieg was 31 In 1970 and 308 in 1985/86. I calculated the United States and Japanese shares of wage and salary employees using the data from the Center for Labour Economics, OECD Data set, updated, and with union figures based as much as possible on the U.S. Bureau of Labor Statistics data. The calculation is crude, using figures for the year closest to 1985 for countries with missing data.

2 - OECD data show that the shift of employment out of manufacturing, was actually larger in OECD Europe than in the de-unionising United States. See OECD Higtorical Statistics (Paris 19B6).

3 - - The rise in favorable ratings of unions in the UK is docunented in Financial Times, November 18,1987. Data on approval of unions in the United States are given by Lipset (198B). Because the U.S. figures are from two separate surveys they are not strictly comparable.

4 - This claim is based on correlating changes in real wages and in density using the ISE-OECD data set.

5 -. The literature here is enormous. The most influential madern econometric paper is by Ashenfelter and Pencavel (1969). 
BLbl lography.

AFL-CIO, Committee on the Evolution of Work, "The Changing situation of Workers and their Unions", Washington D.C. 1985

Ashenfelter, Orley and John Pencavel. "American Trade Union GRowth, 19001960 Quarterly Journal of Economics. August 1969, 434-48.

Block, Richard, Christine Mahoney, and Leslie Corbitt "The Impact of Employment-at-Will Judicial Decisions on the Outcomes of NLRB Representation Elections" Industrial Relacions Reseacch Proceedings of the ThIry-Ninth Annual Meeting (IRRA, 1987)

Bureau of National Affairs Directory of National Unions and Employee Associations, various editions

Chaison, Gary and Joseph Rose, "Continental Divide: The Direction and Fate of North American Unions", McMaster University, Working Papar no 309, Hamilton Canada, September 1988

Crouch, Colin "Conditions for Trade Union Wage Restraint" In Leon Lindberg and Charles Maler (eds) The Politics of Inflation and Economic Stagnation (Brookings, 1985)

Dickens, William "The Effect of Company Campaigns on Certification Elections", Industrial and Labor Relatlons Review, 1983, 36 pp 560.75

Freeman, Richard. "Why are Unions Faring Poorly in NLRB Representation Elections?" In Thomas Kochan ed Challenges and Cholces Facing American Labor (MIT, Cambridge, 1985: pp 45-64)

....- "The Effect of the Union Wage Differential on Management Opposition and Union Organizing Success", American Economic Review, Hay 1986, Pp $92-96$.

...... "UnionIsm and Protective Labor Legislation" Industrlal Relations Research Serles Proceedings of the Thiry-Ninth Annual Meeting (IRRA, 1987) 
and Casey Ichnlowski, When Public Sector Workers UnLonize (Univ

of Chicago, 1988)

........ and James Medoff, "New Estimates of Private Sector Unionism in

the United States" Industrial and Labor Relations Review, 32:2, January 1979

........ and Jeff Pelletier, "The Impact of Industrial Relations

Legislation on Union Density in the United Kingdom and Ireland" National Bureau of Economic Research working paper, forthcoming 1989

....... and Marc Rebbick, "Crumbling Pillar? Declining Union Density In Japan", Conference on Labor Relations and the Firm; Comparative Perspectives, Toky, January 7, 1989

Gompers, Samuel, Labor and the Common Welfare, New York: Arno Press, 1965

Hecksher, Charles, The New Unionism (Basic Books, New York, 1988)

Japan Ministry of Labor, Basic Survey of Labor Unions, Annual (Tokyo)

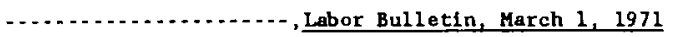

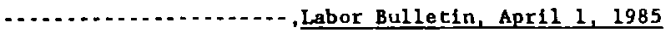

. Foreign Labor Trends, various editions

Kerr, Clark, John Dunlop, Frederick Harbison, and Charles Meyers.

Industrial ism and Industrlal Man (0xford, 1964)

Kochan, Thomas, Robert McKersie, and John Chalykoff, "The Effects of Corporate Strategy and Workplace Innovations on Union Representation", Industrial and Labor Relations Review, July 1986, 487-501.

Financial Times November 18,1987

Kumar, Pradeep, with Mary Lou Coates and David Arrowsmith, The Current Industrial Relations Scene in Ganada: 1986 (Queens University, Kingston,

Canada, 1986)

London School of Economics, Centre for Labour Economics, OECD Data Set, 1986, updated 1988 
Lipset, Seymour Martin, "labor Unions li the Yublic Mind" In Seyinour Martin Lipset, Unlons In Transitlon (ICS, San Francisco, 1986)

McDonald, Charles, "The AFL-CIO Blueprint for the Future - a progress report" Industrial Relations Research Serles Proceedings of the Thiry-Ninth Annual Meoting (IRRA, 1987)

Ministero del Lavoro e Della Previdenza Sociale, Report ' 87 Labour and Employment Polfcies in Italy, (CER-FGB, Italy, 1988)

Neumann, George and Ellen Rissman "Where Have All the Union Members Gone?" Journal of Labor Economics, vol 2, number 2, April 1984 pp $175-192$

Nagashima, Hidesuke "Japanese Labor at a Turning Polnt". Japan Update, Sumer $1988,15-17$

OECD Historical statistics (Paris, OECD, 1986)

United States, Bureau of Labor Statistics, "Union Membership as a Percent of Nonagricultural Wage and Salary Employees, unpublished data, 1988

-... Eraployment and Earnings. January 1988

.... "Selected Earnings and Demographic Characteristics of Union Hembers, 1970, (Report 417), Washington, U.S.G.P.O. 1972

Visser, Jelle "European Trade Unions in Retreat", Conference "Europa im Wandel", Mannheim 15-18 October 1985

Wood, W.D. and Pradeep Kumar, The Current Industrial Relations Scene In Canada: 197? (Queens University, Kingston, Canada, 1977) 